\title{
US chemical weapons production plan
}

$\$ 8,000$ million

\section{5-year spending}

\section{waits in wings}

\section{Washington}

The US Defense Department is using allegations about the military use of supposedly Soviet-produced toxins in South East Asia to boost its campaign for increasing domestic spending on the production of chemical weapons, suspended by President Nixon in 1970 after widespread protest over the use of chemical agents by the United States in Vietnam.

The Reagan Administration is expected to announce a chemical warfare programme costing about $\$ 8,000$ million over the next five years. In addition to upgrading the defensive equipment available to United States armed forces, the money would be used to build a new arsenal of so-called binary chemical weapons.

A classified report, said to contain the principal arguments in favour of restarting chemical weapons production, was sent to Congress in January by President Carter as part of a budget request that included a projection by the Defense Department for spending about $\$ 2,470$ million on the development of such weapons over the next few years. However, a study by a panel of the Defense Science Board, and chaired by Dr John Deutch, professor of chemical engineering at the Massachusetts Institute of Technology and previously UnderSecretary in the Department of Energy, suggested that in view of reports of a growing Soviet capability, this projection shold be increased by between three and four times. Mr Reagan is expected to follow this advice.

Congress has already demonstrated its enthusiasm for such a move. In May, the Senate approved a plan by the Reagan Administration to spend $\$ 20$ million on equipment for a binary nerve gas facility in Pine Bluff, Arkansas - the first step in the Carter-recommended programme.

The decision to proceed with the construction of the binary facility had been partly stimulated by unconfirmed reports that the Soviet Union had been using nerve gas in its occupation of Afghanistan. Similarly, there is still uncertainty about whether mycotoxins have been consciously used as weapons in the conflict between Vietnam and Cambodia - and if so, whether these were produced in the Soviet Union, and are the same agents that were used in Afghanistan, as some official statements have implied.

The present controversy emerged two weeks ago, when US Secretary of State Alexander Haig told a press conference in
West Berlin that the United States now had "firm evidence of the utilization of such weapons in South East Asia". This evidence turned out to be a single example of stem and leaf taken from a plant near the Cambodian border in an area said to have been sprayed with "yellow rain".

The State Department in Washington said that the sample contained "three potent mycotoxins of the trichothecene group" identified as nivalenol, deoxynivalenol and a third known as $\mathrm{T}-2$. Although State Department officials admitted that the evidence was far from conclusive, by drawing attention to the similarities in the symptoms observed in those exposed to "yellow rain" and the known effects of the trichothecene toxins, a natural product of several species of the fungus Fusarium, as well as reporting that the levels of toxins were "up to 20 times greater than any recorded in any natural outbreak", the impression was left that their use had been deliberate.

Several United States scientists expressed concern last week at the haste with which scientific data from a single sample had been used to substantiate charges with wide implications. (Biological weapons are currently prohibited by international treaty.) They pointed out several holes in the State Department's reasoning; for example, where the State Department claimed that such mycotoxins "do not occur naturally in South East Asia", Professor Matthew Meselson has pointed to published reports of T- 2 being found on sorghum in India and in grain in Italy.

Privately, US officials admit that their data were made public earlier than they would have liked. Several other samples are currently being analysed; and the State Department was pushed into making an early public statement partly because some earlier results had been leaked to the press.

However, Reagan Administration officials have not been slow to use such slim scientific data as they have to maximum political advantage. Mr Haig's reference to the apparent evidence of "yellow rain" in his speech in Germany helped him to deflect some of the criticism of the United States for the decision to place nuclear weapons in Europe.

Secretary of Defense Mr Caspar Weinberger last week threatened - somewhat to the embarrassment of the Administration - virtually to reply to the Soviet Union in kind. Answering reporters' questions during an interview broadcast by the "Voice of America", Mr Weinberger said that the United States needed "to make sure that we have some kind of balancing forces" and that knowledge on the part of the Soviets that they might face "retaliation in kind might be a deterrent

\section{UK universities to tackle new minister}

The Committee of Vice-Chancellors and Principals of Britain's forty-four universities hopes to persuade Sir Keith Joseph, the new Secretary of State for Education, of the error of the government's decision to cut the grant to the universities by eight per cent over the next three years. It has called for a meeting with Sir Keith at the earliest opportunity.

Central to the committee's argument is that any savings the government hopes to make will be substantially eaten into by payments of compensation to redundant university staff. It hopes to persuade Sir Keith either to make the cuts over a longer period or to rethink the policy of charging economic fees to overseas students, which this year has resulted in a 35 per cent shortfall in the number of overseas applicants for university places. Although the number of overseas students taking up offers of places will not be known for a few weeks, universities estimate that the shortfall will be sufficient to add considerably to their financial difficulties.

The vice-chancellors, who met last week to discuss the cuts, also report that many well-qualified home applicants have not found university places this year. To meet the government's objectives, they alsc estimate that ten per cent fewer will be successful in 1982 and 1983. At a time when the number of 18 year olds in the popu- lation is increasing, they argue that money would be better spent on providing educational opportunities than on paying off redundant staff.

Although some universities have begun to estimate the number and cost of redundancies, the position will probably remain uncertain until January, when the vicechancellors plan to put a more detailed estimate of cost to the government. But Dr Albert Sloman, chairman of the vicechancellors' committee, sees no reason to reduce his first estimate of 3,000 academic redundancies in the next three years.

The committee has also begun formulating national guidelines for redundancy payments. The objective is a scheme to ensure that all university staff are treated fairly. One snag is that contracts of tenure vary considerably between and even within institutions. Another is devising a scheme attractive enough to persuade staff to leave voluntarily and yet not so generous that the government would reject it out of hand.

The vice-chancellors have also embarked on rethinking academic career structures. They apparently consider that some form of tenure is essential, but plan to find a form of contract that also provides universities with a let-out in hard times. The aim is to eliminate "copper-bottomed" contracts with no let-out clauses, at present enjoyed by only some academics. Judy Redfearn 
that would prevent these things from ever having been used".

Following apparent complaints from State Department officials about the possible implications of the secretary's comments, the "Voice of America" added a statement to the interview reaffirming the United States's renunciation of biological and toxin weapons. It explained that "retaliation in kind" meant "redressing the imbalance through the development of an adequate protective posture".

\section{David Dickson}

\section{International nuclear agency Changing sides?}

\section{Stockholm}

The man who led the campaign in Sweden in 1980 to reduce nuclear power to only a stopgap option, to be abandoned when renewable energy sources become economic, has been appointed Secretary General of the International Atomic Energy Agency (IAEA).

The primary role of IAEA - a United Nations agency - has been to promote the peaceful uses of nuclear energy: a role which has given it a prominent part in the debate over energy supplies to the Third World and potential nuclear proliferation. So the appointment last week of Dr Hans M. Blix, 58, Sweden's deputy foreign minister and an environmentalist, is somewhat controversial.

Until 1978 Blix was a senior civil servant specializing in international law - in which he earlier held a professorship. But with the collapse of the 1976 conservative government he was drawn into politics on behalf of the Liberal Party. As deputy foreign minister he has concentrated on Sweden's aid to developing countries, making Sweden one of the few to reach the United Nations target of 1 per cent of gross national product. It is this interest and success with the Third World which has no doubt won him the secretary generalship of the IAEA.

In the 1980 referendum on nuclear power in Sweden, Blix campaigned for the winning "middle line": increasing the number of nuclear power stations from 6 to 12 in the next few years, but then holding the number at 12 if alternative sources such as solar power or biomass (a realistic option in Sweden with its vast number of trees) are then viable.

However, Blix said this week in an interview with the Stockholm newspaper Dagfens Nyheter that he did not see IAEA as a place to peddle his own views. His job will be to implement what can be agreed. $\mathrm{He}$ failed to mention that what can and cannot be agreed is, to a degree, under the influence of the IAEA secretary general.

There were three areas that IAEA should pursue, he said. First, its traditional role of furthering the peaceful uses of nuclear power - though he would like to see more nations adhering to the non-proliferation treaty. Blix is greatly interested in the idea of the creation of a nuclear weapon-free zone in the Middle East. Although he has made no public comment yet on the question of the use and international control (through IAEA) of the French reactors supplied to Iraq and recently bombed by Israel for fear of Iraq developing nuclear weapons, he did say in the interview that the control of nuclear power was "very important" - and that that control works very well today.

The second area in which IAEA should give assistance is in nuclear safety, both in reactors and waste disposal, Blix said: here there should be an international exchange of experience and a degree of open debate. "I came to realize the importance of this during the Swedish referendum", he commented. The third role for IAEA was support of developing countries in the

\section{More science cuts \\ Washington}

Further proposed cuts in American science programmes are expected to be announced shortly following President Reagan's announcement of an acrossthe-board cut of 12 per cent in the discretionary spending budgets of all federal agencies.

Basic science did relatively well in the President's original budget proposals to Congress in March, which envisaged keeping research spending virtually constant in real terms. The new round of cuts, made necessary by indications that even the original cuts were not likely to be sufficient to satisfy the Wall Street bond market, mean that spending on science in real terms would drop by at least 10 per cent in the fiscal year which begins on 1 October, the first drop since 1974.

Individual agencies, such as the National Science Foundation and the National Aeronautics and Space Administration (NASA), have yet to decide precisely where the cuts would fall. But the magnitude of the cuts - about $\$ 600$ million in the case of NASA means that many research projects would inevitably be terminated.

In high energy physics, for example, $\mathrm{Dr}$ Sidney Drell, deputy director of the Stanford Linear Accelerator Center and chairman of the Department of Energy's high energy physics advisory panel, said on Monday that the result would probably mean about a 20 per cent reduction in the level of operations. He expected hundreds of personnel to be laid off from the country's national laboratories, and that many planned experiments would not now take place.

Addressing a meeting of the panel, the President's Science Advisor, Dr George A. Keyworth, said that the new rounds of cuts made his earlier remarks about the need to choose priorities for the support of science "even more relevant today than three months ago". David Dickson analytical and other uses of radionuclides.

Carl Tham, Swedish spokesman at IAEA, said this week that more important than Dr Blix's position during the Swedish referendum was his immense experience in international relations. Robert Walgate

\section{Heidelberg cancer centre Neurath's case}

Dr Hans Neurath, whose resignation as Director of the German Cancer Research Centre at Heidelberg was announced in June (see Nature 20 August, p.665 and subsequent correspondence 24 September, p.252), gave the centre's board of trustees a critical and even bitter explanation on 23 September. In his statement, Dr Neurath said that he had found it impracticable to carry through agreed proposals for running the centre because of the circumstances, "structural, scientific and concerning personnel", at the centre.

Dr Neurath's departure from the centre will take effect on 31 December. In his statement to the board of trustees, he noted that his appointment had been made so that he could improve the quality of cancer research at Heidelberg and "bring it up to an international standard".

In reality, the statement continued, he had found the institution to be "plagued by serious and perhaps irreconcilable conflicts of interest", largely stemming from an "old established majority". Dr Neurath said that his impression was that "procedural questions and administrative and legal arguments" have priority over scientific work, and that scientific leadership is impeded by over-literal interpretations of the centre's charter.

Dr Neurath also said in his statement last week that he had been denied the active support both of the trustees to whom his statement was addressed and of the representatives of government ministries. He complained that those concerned had supported him by words and not by deeds, thus undermining the prospects for his success as director.

The statement added that Dr Neurath decided to resign in the hope that such a drastic step might contribute to reform.

\section{Polish higher education \\ Bill progressing}

Poland's controversial new bill on higher education is to go forward for discussion by the Council of Ministers "without essential changes". So promised the Minister for Science, Higher Education and Technology, Dr Jerzy Nawrocki in a statement intended to put an end to "unjustified fears and extreme protest movements",

The protests, which have now spread to virtually all universities and higher educational institutions in Poland, were triggered off by the the last-minute changes 